
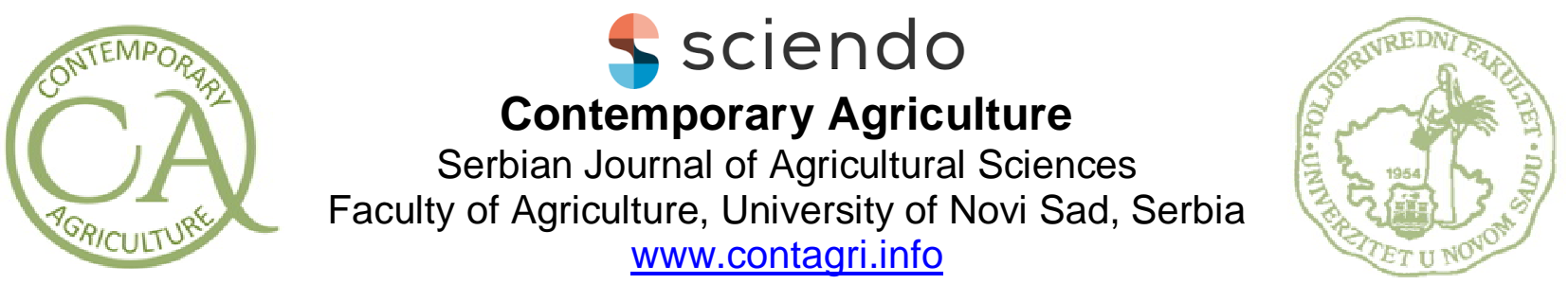

Original scientific paper

UDC: 599.731 .1

DOI: 10.2478/contagri-2019-0011

\title{
EFFECTS OF ANTIBIOTIC DILUENT ADDITIVES ON THE MOTILITY PARAMETERS AND MORPHOLOGICAL INTEGRITY OF BOAR SPERM DURING SIX DAYS OF STORAGE
}

\author{
STOJA JOTANOVIĆ, BORISLAV PENO, SINIŠA MANDIĆ, ĐORĐE SAVIĆ*, MARINKO \\ VEKIĆ, MARIJA JOVIČIĆ \\ Institute for Reproduction of Domestic Animals, Faculty of Agriculture, University of Banja Luka, Bulevar vojvode \\ Petra Bojovića 1a, 78000, Banja Luka, Bosnia and Herzegovina \\ *Corresponding author: djordje.savic@agro.unibl.org
}

\begin{abstract}
SUMMARY
The purpose of this paper is to examine the effect of antibiotic diluent additives on the motility and morphological integrity of diluted fresh boar semen during a six-day storage period. A total of 60 insemination doses, originating from two Landrace boars, were examined and allocated to control $(C, n=30$, diluted with BTS) and experimental groups ( $E, n=30$, diluted with BTS upon antibiotic addition). The treatment applied exerted positive effects on the preservation of progressive motility, percentage of live sperm and HOS test results $(70.24$ vs. $66.53 \%, 71.54$ vs. $69.77 \%, 67.35$ vs. $64.17 \%$ and 64.10 vs. $54.26 \% ; 91.15$ vs. $90.02 \%, 88.38$ vs. $85.55 \%, 81.50$ vs. $76.13 \%$ and 74.53 vs. $68.72 \%$; and 93.35 vs. $92.40 \%, 91.04$ vs. $88.02 \%, 84.67$ vs. $78.15 \%$ and 77.27 vs. $69.44 \%$ HOS sperm for the $1^{\text {st }}, 3^{\text {rd }}, 5^{\text {th }}$ and $6^{\text {th }}$ day of storage, respectively). The results obtained indicate that the treatment applied has a favourable effect on preserving the quality parameters of diluted fresh boar semen during storage, resulting most likely from a reduction of bacterial contamination.
\end{abstract}

Key words: boar semen, diluents, antibiotic additive, quality

\section{INTRODUCTION}

Artificial insemination of sows has been widely used in modern swine breeding since the beginning of the $20^{\text {th }}$ century. Boar semen is sensible to freezing procedures due to low cholesterol levels and high levels of polyunsaturated fatty acids in cell membranes (Cerolini et al., 2000; Rath et al., 2009). Accordingly, the technology of swine insemination is mainly based on the use of diluted fresh semen (Gadea, 2003; Knox, 2016, Pezo et al., 2019). As diluted fresh boar semen is usually stored at $17^{\circ} \mathrm{C}$ and contains substances favourable to bacterial growth, one of the greatest problems with its usage is bacterial contamination through sampling and storage (Yeste, 2017). Some research showed bacterial contamination in $75 \%$ of the samples analysed, with Escherichia colli as the most common finding (Maroto Martin et al., 2010). According to Althouse et al. (2000) and Althouse and Lu (2005), bacterial contamination has a negative impact on semen quality through an increased incidence of sperm agglutination and acrosomal damage, a decreased percent of progressive motility and a decreased vitality of sperm. Furthermore, negative impacts of bacterial contamination on sperm vitality can be indirect, i.e. through a decrease in $\mathrm{pH}$ and consumption of energy sources, changes of osmotic concentration and osmotic pressure in the medium, and the induction of antisperm antibody production. The bacterial contamination of semen doses can also lower the percent of conception and increase the incidence of early embryonic mortality and endometritis in sows (Martin et al., 2010; Jotanović \& Savić, 2017).

In order to get more insemination doses from one ejaculate, boar semen is diluted with different diluents. The role of diluents is to reduce the metabolic activity of sperm, preserve its vitality and fertilization ability (Johnson et al., 
2000), provide the necessary nutrients for the maintenance of sperm metabolism (Mapeka et al., 2012), maintain a $\mathrm{pH}$ of between 6.8-7.2, stabilize the plasma membrane, regulate the osmotic pressure to which spermatozoa are exposed, and prevent bacterial growth. Semen diluents mainly consist of glucose (as a source of energy), protective substances against the thermal shock (eg BSA, Bovine Serum Albumin), buffering salts (in order to avoid the negative effects of the $\mathrm{pH}$ change (sodium bicarbonate, sodium citrate, TRIS)), basic salts (that provide an appropriate osmotic balance $(\mathrm{NaCl}, \mathrm{KCl})$ ) and antibiotics (to prevent bacterial growth) (Paquinon et al., 1988; Gadea et al., 2004; Gogol et al., 2009).

The quality of diluents for boar semen is evaluated relative to their ability to preserve the vitality and fertilization ability of spermatozoa during the storage period (Gadea, 2003; Gadea et al., 2004). The vitality and fertilization ability of spermatozoa, and the degree of their preservation during the storage period, used to be estimated according to their progressive motility and morphological integrity. However, more sophisticated methods are in use at present, such as the CASA method, for determining the motility parameters of individual spermatozoa (namely the amplitude of lateral head displacement (ALH), average path velocity (VAP), curvilinear velocity (VCL), straight-line velocity (VSL), straightness (STR) and linearity (LIN)) (Jotanović \& Savić, 2017).

Antibiotics are a standard ingredient in diluents for boar semen, and are one of the key factors for preserving the vitality of spermatozoa and the overall fertilization ability of the insemination dose (Althouse, 2005; Althouse, 2008, Waberski et al., 2019). The long-term use of antibiotics in diluents for boar semen often results in the development of bacterial resistance, so antibiotics need to be changed periodically. One method of controlling the bacterial contamination of boar semen and resolving the problem of the resistance to antibiotics is the use of antibiotic cocktails when taking ejaculate samples. Such practice preserves the vitality and fertilization ability of sperm, as well as the parameters of its motility during the storage period by reducing the initial bacterial contamination (Sone, 1990; Althouse, 2008; Huerta et al., 2011, Bresciani et al., 2013, Bryla \& Trzcinska, 2015). The purpose of this paper is to examine the effect of antibiotic diluent additives on the motility and morphological integrity of diluted fresh boar semen during a six-day storage period.

\section{MATERIALS AND METHODS}

Commercial insemination doses, originating from two Landrace boars aged 36 and 40 months, were purchased from a private farm and analysed at the Laboratory for Reproduction of Domestic Animals at the Faculty of Agriculture, the University of Banja Luka (Bosnia and Herzegovina). The sperm-enriched fraction of the ejaculate obtained was taken by the manual method of penis fixation. One half of the ejaculates (control group, $\mathrm{C}, \mathrm{n}=10$ ) were diluted with a standard procedure using a commercial diluent for boar semen (Beltsville Thawing Solution, BTS). The other half of the ejaculates (experimental group, $\mathrm{E}, \mathrm{n}=10$ ) were treated with an antibiotic preparation Dicol (Magapor, Spain) immediately after sampling, in order to reduce the level of bacterial contamination, and then diluted with a standard procedure using the same commercial diluent. The diluent (BTS) and the diluent supplement (Dicol) were prepared on the day of ejaculate sampling. In order to eliminate the effect of the dose on the tested parameters, three doses of the insemination were taken from each ejaculate, which makes a total of 30 doses per boar (i.e. 60 doses in total).

For the purposes of this study, only the insemination doses meeting the set quality requirements (i.e. a minimum of $70 \%$ of the motile spermatozoa and a minimal total number of spermatozoa of $3 \times 10^{9}$ per dose) were used. After preparation, the insemination doses were transported to the laboratory and stored in an air-conditioned box at $17^{\circ} \mathrm{C}$ for six days. The evaluation of the insemination doses relative to the parameters of motility and morphological integrity of spermatozoa was performed on days 1, 3, 5 and 6 after taking the ejaculate samples.

The determination of the parameters of the sperm motility was performed using the Computer Assisted Sperm Analysis (CASA; Japan and Laboratory Imaging System) containing the Eclipse Ci microscope (Nikon, Tokyo, Japan), equipped with a 10x negative phase-contrast lens (Nikon, Tokyo, Japan) and the DMK 31AU03 digital camera (The Imaging Source, Bremen, Germany). Prior to analysis, the semen samples were heated in a water bath at $38^{\circ} \mathrm{C}$, and $3 \mu \mathrm{l}$ of diluted semen was put into the Leja Standard Count Chamber Slide (Leja ${ }^{\circledR}$, GN Nieuw-Vennep, Netherlands). A total of 6 parameters of sperm kinetics were determined: amplitude of lateral head displacement $(\mathrm{ALH}, \mu \mathrm{m})$, average path velocity (VAP, $\mu \mathrm{m} / \mathrm{s}$ ), curvilinear velocity (VCL, $\mu \mathrm{m} / \mathrm{s}$ ), straight-line velocity (VSL, $\mu \mathrm{m} / \mathrm{s}$ ), straightness (STR, (VSL/VAP) $\times 100$ ) and linearity (LIN, (VSL/VCL) $\times 100)$.

On the basis of the previous experience with the CASA system at the Laboratory for Reproduction of Domestic Animals at the Faculty of Agriculture, the University of Banja Luka (Bosnia and Herzegovina), the spermatozoa with VAP $>10 \mu \mathrm{m} / \mathrm{s}$ were classified as motile and taken into account for calculating the values of the motility parameters. To evaluate the morphological integrity of spermatozoa, the supravital staining of spermatozoa by eosin-nigrosin was performed (according to Blom 1950) in combination with the HOS (Hypoosmotic Swelling Test) test (Jeyendran et 
al., 1984). For each sample, a minimal count of 200 spermatozoa was evaluated, under an immersive lens (100xA/1.25 Oil Ph3 DL), and classified into the following categories: live (intact head plasma membrane), dead, defect head plasma membrane, intact tail plasma membrane (HOS+), and damaged tail plasma membrane (HOS).Only HOS+ sperms are shown in the tables.

The data were processed using the descriptive statistics method and the analysis of the two-factor variance followed by the post-hoc Tukey test. For statistical analysis, the software package SPSS 22 (IBM 2013) was used.

\section{RESULTS AND DISCUSSION}

The technology of producing boar semen insemination doses and their use for sow insemination is based on the use of diluted fresh semen, kept at $15-17^{\circ} \mathrm{C}$ (Knox, 2016). Such storage conditions are favourable to the development of bacteria during semen handling and the storage of insemination doses (Goldberg et al., 2013; Schulze et al., 2015). The presence of bacteria in the semen is associated with a decrease in the quality of the insemination doses due to the consumption of nutrients, agglutination and damage to spermatozoa, changes in the $\mathrm{pH}$ of the medium in which spermatozoids are present, and the overall negative effect on the motility and vitality of spermatozoa (Althouse et al., 2000; Ubeda et al., 2013). Therefore, the bacterial contamination of sperm is one of the key factors which limits the period of utilization of insemination doses in practice (Althouse \& Lu, 2005).

Antibiotics are added to diluents in order to reduce the initial contamination of the semen at the moment of sample taking, and to slow down the development of bacteria in the diluted semen (Althouse, 2008). In recent years, antibiotic cocktails have been used as additives to standard diluents, which are added to the semen at sample taking and before dilution (Waberski et al., 2010; Bresciani et al., 2013; Bryla \& Trzcinska, 2015; Jotanović \& Savić, 2017). Previous studies indicate a positive effect of this treatment on the reduction of bacterial contamination, the preservation of the quality parameters and the overall fertilization capacity of the insemination doses during the storage period (Dias et al., 2000) (allowing for their use over a longer period of time compared to the insemination doses produced using the standard procedure). Some of these additives are used individually as diluents, and also exert positive effects on preserving the quality parameters of the insemination doses. The positive effect of the treatment with antibiotic cocktails on the reduction of bacterial contamination of boar semen is confirmed by the results reported by Suwimonteerabtur et al. (2011) and Dahmani et al. (2015). The authors compared the level of contamination of the semen diluted with the standard procedure and the one treated with antibiotic cocktails during sample taking. They ultimately found that the contamination level of the semen in the group treated with antibiotic cocktails was far lower, rendering these semen samples more favourable from the quality perspective than the semen diluted using the standard procedure.

The motility parameters of the examined sperm samples during six days of storage are presented in Table 1 .

Table 1. Parameters of sperm motility during six days of storage $(\mathrm{M} \pm \mathrm{SE})$

\begin{tabular}{|c|c|c|c|c|c|c|c|c|}
\hline $\begin{array}{c}\text { Storage } \\
\text { (days) }\end{array}$ & Group & $\begin{array}{c}\text { Progressive } \\
\text { motility } \\
(\%)\end{array}$ & $\begin{array}{l}\text { ALH } \\
(\mu \mathrm{m})\end{array}$ & $\begin{array}{l}\text { VAP } \\
(\mu \mathrm{m} / \mathrm{s})\end{array}$ & $\begin{array}{l}\text { VCL } \\
(\mu \mathrm{m} / \mathrm{s})\end{array}$ & $\begin{array}{l}\text { VSL } \\
(\mu \mathrm{m} / \mathrm{s})\end{array}$ & $\begin{array}{c}\text { STR } \\
(\%)\end{array}$ & $\begin{array}{l}\text { LIN } \\
(\%)\end{array}$ \\
\hline \multirow[b]{2}{*}{1} & $\mathrm{C}$ & $66.53 \pm 2.76^{\mathrm{ABa}}$ & $5.45 \pm 0.13$ & $35.38 \pm 1.48^{\mathrm{ab}}$ & $85.64 \pm 3.10^{\mathrm{ABa}}$ & $14.77 \pm 0.45^{\mathrm{Cb}}$ & $49.63 \pm 2.70^{\mathrm{B}}$ & $21.20 \pm 1.09^{C}$ \\
\hline & $\mathrm{E}$ & $70.24 \pm 2.28^{\mathrm{A}}$ & $5.34 \pm 0.13$ & $37.81 \pm 1.09^{\mathrm{a}}$ & $86.52 \pm 2.17^{\mathrm{Ab}}$ & $15.97 \pm 0.43^{\mathrm{C}}$ & $49.34 \pm 1.62^{\mathrm{B}}$ & $22.39 \pm 0.75^{\mathrm{BCa}}$ \\
\hline \multirow{2}{*}{3} & $\mathrm{C}$ & $69.77 \pm 1.85^{\mathrm{A}}$ & $5.32 \pm 0.12$ & $35.84 \pm 1.07^{\mathrm{ab}}$ & $77.38 \pm 2.95^{\mathrm{AB}}$ & $20.68 \pm 1.10^{\mathrm{B}}$ & $62.64 \pm 3.31^{\mathrm{A}}$ & $31.87 \pm 2.32^{\mathrm{A}}$ \\
\hline & $\mathrm{E}$ & $71.54 \pm 1.84^{\mathrm{A}}$ & $5.48 \pm 0.11$ & $36.64 \pm 1.28^{\mathrm{ab}}$ & $85.42 \pm 2.74^{\mathrm{ABa}}$ & $17.64 \pm 0.36^{\mathrm{BCb}}$ & $55.01 \pm 1.79^{\mathrm{AB}}$ & $25.23 \pm 0.93^{\mathrm{ACa}}$ \\
\hline \multirow{2}{*}{5} & $\mathrm{C}$ & $64.17 \pm 3.03^{\mathrm{AB}}$ & $5.25 \pm 0.11$ & $34.19 \pm 1.25^{\mathrm{ab}}$ & $73.73 \pm 2.57^{\mathrm{Bb}}$ & $21.57 \pm 1.46^{\mathrm{ABa}}$ & $65.27 \pm 3.13^{\mathrm{A}}$ & $33.37 \pm 2.55^{\mathrm{Ab}}$ \\
\hline & $\mathrm{E}$ & $67.35 \pm 1.81^{\mathrm{A}}$ & $5.50 \pm 0.11$ & $33.88 \pm 0.88^{\mathrm{ab}}$ & $78.88 \pm 2.09^{\mathrm{AB}}$ & $19.10 \pm 0.56^{\mathrm{BCa}}$ & $61.88 \pm 1.88^{\mathrm{A}}$ & $28.61 \pm 1.13^{\mathrm{ABCb}}$ \\
\hline \multirow{2}{*}{6} & $\mathrm{C}$ & $54.26 \pm 4.00^{\mathrm{Bb}}$ & $5.37 \pm 0.10$ & $34.42 \pm 1.13^{\mathrm{ab}}$ & $76.86 \pm 2.42^{\mathrm{AB}}$ & $21.69 \pm 1.39^{\mathrm{ABa}}$ & $65.55 \pm 2.90^{\mathrm{A}}$ & $32.62 \pm 2.46^{\mathrm{Ab}}$ \\
\hline & $\mathrm{E}$ & $64.10 \pm 2.65^{\mathrm{AB}}$ & $5.30 \pm 0.10$ & $32.18 \pm 1.00^{\mathrm{b}}$ & $74.52 \pm 2.21^{\mathrm{ABb}}$ & $19.52 \pm 0.64^{\mathrm{AB}}$ & $65.09 \pm 1.80^{\mathrm{A}}$ & $29.95 \pm 1.13^{\mathrm{AB}}$ \\
\hline \multicolumn{9}{|l|}{$\mathrm{p}$ values } \\
\hline \multicolumn{2}{|c|}{ Storage } & $<0.01$ & 0 & $<0.01$ & $<0.01$ & $<0.01$ & $<0.01$ & $<0.01$ \\
\hline \multicolumn{2}{|c|}{ Group } & 0.01 & 0.48 & 0.84 & 0.11 & 0.01 & 0.10 & $<0.01$ \\
\hline \multicolumn{2}{|c|}{ Storage x Group } & 0.14 & 0.35 & 0.23 & 0.19 & 0.08 & 0.41 & 0.15 \\
\hline
\end{tabular}

C- control group; E-experimental group; Values with different letters are statistically different (capital letters $p<0.01$; small letters $\mathrm{p}<0.05)$.

The data shown in Table 1 indicate a statistically significant effect of the storage period on the preservation of the percentage of progressive mobility of spermatozoa, as well as the kinetic parameters of their motility. Although 
gradually declining trends of the percentage of progressively motile spermatozoa were found in both the experimental and control groups, its value was higher in the experimental during the entire experimental period. This unequivocally indicates the positive effect of the applied treatment on the preservation of the progressive motility of spermatozoa. Santos et al. (2018) examined the progressive motility of boar semen diluted with the Dicol antibiotic preparation (which used also in our study), and found that it remained high even after four days of storage (90.87\%), which can be attributed to the effect of the diluent used. The results of our study suggest that the percentage of progressive motility of spermatozoa in the experimental group was higher than in the control group during the entire period under consideration $(70.24$ vs. $66.53 \%, 71.54$ vs. $69.77 \%, 67.35$ vs. $64.17 \%$ and 64.10 vs. $54.26 \%$, for the first, third, fifth and sixth day of storage, respectively), indicating that the applied treatment positively influenced the preservation of the percentage of progressive motility. The values obtained in the present study are lower than those reported by Santos et al. (2018), which is most likely a consequence of the design of the experiment and the fact that these authors used Dicol as an independent diluent in contrast to our study wherein Dicol was used only as an additive to a standard commercial diluent. The storage period greatly influences the quality of insemination doses, especially the percentage of progressive motility that gradually decreases with the length of storage (Kommisrud et al., 2002) (which is consistent with our results). As only progressively motile spermatozoa are potentially fertile, it is expected that the decline in the percentage of progressive mobility and the values of parameters of the sperm motility (VCL, VAP, VSL, ALH) will result in a decrease in the overall fertilization capacity of the insemination dose (Holt et al., 1994), and thus lower the results of insemination (Martin et al., 2010).

The ALH values in both groups examined were approximately equal during the entire experimental period. The VAP and VCL values indicated a tendency to a gradual decline during the storage period in both groups examined, whereas the values of VSL, STR and LIN showed a gradual increase during the entire storage period. In contrast to the percentage of progressively motile spermatozoa, the treatment applied did not clearly exert positive effects on the kinetic parameters of the motility of spermatozoa, as indicated by the statistical significance of differences that occur only between the VSL and LIN values obtained. The results of our study do not indicate significant deviations in the values of the parameters of the motility of spermatozoa compared to the applied treatment. However, they do indicate a statistically significant effect of the storage period. Such a result is expected as only the sperm samples that were moving progressively with the velocity exceeding the set limit of VAP $>10 \mu \mathrm{m} / \mathrm{s}$ were taken into account when determining the value of motility parameters. According to Freking et al. (2012), the sperm with VCL exceeding the $10 \mu \mathrm{m} / \mathrm{s}$ threshold is classified as motile, that with VCL $>25 \mu \mathrm{m} / \mathrm{s}$ as progressively motile, whereas Vyt et al. (2008) consider sperm with STR> $45 \%$ as progressively motile. If these data are applied to the results of our study, it can be said that the average values of the parameters of the sperm motility were above the limit in both examined groups during the entire period under consideration, which indicates that the examined insemination doses quality was satisfactory in both groups examined relative to the parameters of sperm motility. However, if the sperm motility parameters of the experimental and control groups are observed in parallel, it can be concluded that the fertilization ability of the experimental insemination doses was greater than that of the control group during the entire storage period, and that these doses met the set quality standards even after six days of storage (in contrast to the control ones).

In addition to the parameters of motility, the morphological integrity of spermatozoa was also examined in this study, as one of the most important factors for assessing the quality of boar semen. Good quality ejaculates should have at least 85\% live spermatozoa with intact membranes (Buxade, 1984; Briz, 1994; Briz et al., 1995; Bonet et al., 1995; Sancho Badell, 2002). Similar to other quality parameters, the percentage of spermatozoa with intact membranes decreases during the storage period, which is affected by a number of factors such as the level of bacterial contamination.

The values of the morphological integrity of spermatozoa during six days of storage are presented in Table 2.

Table 2. Values of the morphological integrity of spermatozoa during six days of storage $(\mathrm{M} \pm \mathrm{SE})$

\begin{tabular}{cccc}
\hline $\begin{array}{c}\text { Storage } \\
\text { (days) }\end{array}$ & Group & Live sperms $(\%)$ & HOS+ sperms $(\%)$ \\
\hline 1 & C & $90.02 \pm 0.86^{\mathrm{A}}$ & $92.40 \pm 0.7^{\mathrm{A}}$ \\
& $\mathrm{E}$ & $91.15 \pm 1.26^{\mathrm{Aa}}$ & $93.35 \pm 1.09^{\mathrm{A}}$ \\
3 & $\mathrm{C}$ & $85.55 \pm 1.22^{\mathrm{Ba}}$ & $88.02 \pm 1.30^{\mathrm{B}}$ \\
& $\mathrm{E}$ & $88.38 \pm 1.07^{\mathrm{ABb}}$ & $91.04 \pm 0.9^{\mathrm{A}}$ \\
5 & $\mathrm{C}$ & $76.13 \pm 1.31^{\mathrm{D}}$ & $78.15 \pm 1.42^{\mathrm{C}}$ \\
6 & $\mathrm{E}$ & $81.50 \pm 1.29^{\mathrm{C}}$ & $84.67 \pm 1.18^{\mathrm{D}}$
\end{tabular}




\begin{tabular}{|c|c|c|c|}
\hline & $\mathrm{E}$ & $74.53 \pm 1.41^{\mathrm{D}}$ & $77.27 \pm 1.32^{\mathrm{C}}$ \\
\hline $\mathrm{p}$ values & & & \\
\hline Storage & & $<0.01$ & $<0.01$ \\
\hline Group & & $<0.01$ & $<0.01$ \\
\hline Storage $\mathrm{x}$ group & & $<0.01$ & $<0.01$ \\
\hline
\end{tabular}

C- control group; E-experimental group; Values with different letters are statistically different (capital letters p<0.01; small letters $\mathrm{p}<0.05)$

The data presented in Table 2 indicate the statistically significant effect of the storage period and the treatment applied on the percentage of live spermatozoa, as well as the results of the HOS test, which is noteworthy on the fifth and sixth day of the storage. Huo et al. (2002) examined the percentage of live spermatozoa in semen diluted with BTS during the five-day storage period and found values of $90.08 \%, 86.50 \%$ and $83.45 \%$ for the first, third and fifth day of storage, respectively. Our results indicated positive impacts of the treatment applied on preserving the percentage of live sperms during a six-day storage period ( 91.15 vs. $90.02 \%, 88.38$ vs. $85.55 \%, 81.50$ vs. $76.13 \%$ and 74.53 vs. $68.72 \%$ for the first, third and fifth day of storage, respectively), which is in line with the claims of these authors. Although in both groups there is a noticeable trend of the gradual decline during the storage period, the percentages of living sperms and the results of the HOS test established in the experimental and control group indicate the positive effect of the applied treatment on the preservation of the vitality of spermatozoa and the overall fertilization ability of the insemination doses (which fully meets the quality standards even after six days of storage in the case of the experimental groups). The storage period had a statistically significant effect on the percentage of live spermatozoa, as well as the preservation of their morphological integrity. These results were also (statistically) significantly affected by the treatment applied, as well as the interaction between the applied treatment and the storage period.

\section{CONCLUSION}

The results obtained in the present study suggest that antibiotic supplements to diluents exert a favourable effect on preserving the parameters of the motility and morphological integrity of diluted fresh boar semen during six days of storage, which is probably a consequence of a reduction of bacterial contamination. Therefore, it can be concluded that the use of antibiotic supplements to diluents for boar semen is desirable in practice on account of the enhanced quality and the prolonged shelf life of insemination doses.

\section{REFERENCES}

Althouse C.G. \& Lu K.G. (2005): Bacteriospermia in extended porcine semen. Theriogenology, 63(2): 573-584.

Althouse G.C. (2008): Sanitary procedures for the production of extended semen. Reproduction in Domestic Animals, 43: 374378.

Althouse G.C., Kuster C.E., Clark S.G., Weisiger R.M. (2000): Field investigations of bacterial contaminants and their effects on extended porcine semen. Theriogenology, 53: 1167-76.

Blom E. (1950): A one-minute live-dead sperm stain by means of eosin-nigrosin. Fertility and Sterility, 1: 176-177.

Bonet S., Briz M., Pinart E., Camps R., Fradera A. et al. (1995): Light microscopy characterization of sperm morphology. Microscopy and Analysis, 9: 29-31.

Bresciani C., Morini G., Bettini R., Bigliardi E., Di Ianni F., Cabassi C.S., Sabbioni A., Parmigiani E. (2013): Reproductive efficiency of a new modified boar semen extender for liquid storage. Livestock Science, 157: 384-388.

Briz M. (1994): Microscopical analysis of the ejaculated sperm and the sperm epididymal maturation of Sus domesticus. PhD Thesis, Universitat de Girona.

Briz M.D., Bonet S., Pinart B., Egozcue J., Camps R. (1995): Comparative study of boar sperm coming from the caput, corpus, and cauda regions of the epididymis. Journal of Andrology, 16(2): 175-188.

Bryła M. \& Trzcińska, M. (2015): Quality and fertilizing capacity of boar spermatozoa during liquid storage in extender supplemented with different antibiotics. Animal Reproduction Science, 163: 157-163.

Buxade C.C. (1984): Ganado Porcino: Sistemas de explotacion y tecnicas de produccion. Mundi-Prensa. Madrid, Spain.

Cerolini S., Maldjian A., Surai P., Noble R. (2000): Viability, susceptibility to peroxidation and fatty acid composition of boar semen during liquid storage. Animal Reproduction Science, 58(1-2): 99-111.

Dahmani Y., Ausejo R., Mendoza N., Yeregui J. (2015): Antibacterial efficiency of Dicol and reduction of antibiotics use in boar semen doses. Reproduction of Domestic Animals, 50 (Supplement 2): 126.

Dias C.P., Castagna, C.D., Reis G.R., Simonetti R., Bortolozzo, F.P., Wentz I., Cardoso M. (2000): Grau de contaminação bacteriana no ejaculado de suínos submetidos a dois métodos de higienização e coleta. Arquivos da faculdade de veterinária UFRGS, 28: 32-40. 
Freking B.A., Purdy P.H., Spiller S.F., Welsh C.S., Blackburn H.D. (2012): Boar sperm quality in lines of pigs selected for either ovulation rate or uterine capacity. Journal of Animal Sciences, 90(8): 2515-2523.

Gadea J. (2003): Review: Semen extenders used in the artificial insemination of swine. Spanish Journal of Agricultural Research, $1(2): 17-27$.

Gadea J., Selles E., Marco M.A. (2004): The predictive value of porcine seminal parameters on fertility outcome under commercial conditions. Reproduction in Domestic Animals, 39(5): 303-308.

Gogol P., Szczesniak-Fabianczyk B., Wierzchos-Hilczer A. (2009): The photon emission, ATP level and motility of boar spermatozoa during liquid storage. Reproductive Biology, 9(1): 39-49.

Goldberg A.M.G., Argenti L.E., Faccin J.E., Linck L., Santi M., Bernardi M.L., Cardoso M.R.I., Wentz I., Bortolozzo F.P. (2013): Risk factors for bacterial contamination during boar semen collection, Research in Veterinary Science, 95: 362367.

Holt W., Watson P., Curry M., Holt C. (1994): Reproducibility of Computer-aided Semen Analysis: Comparison of Five Different Systems Used in a Practical Workshop. Fertiliy and Sterility, 62(6): 1277-1282.

Huerta I., Dahmani Y., Ausejo R., Ubeda J.L. (2011): A new tool for control of bacterial contamination in boar semen. Spain. Allen D. Leman Swine Conference, pp. 288.

Huo L.J., Ma X.H., Yang Z.M. (2002): Assesment of sperm viability, mitochondrial activity, capacitation and acrosome intactness in extended boar semen during long-term storage. Theriogenology, 58(7): 1349-1360.

Jeyendran R.S., Van der Ven H.H., Perez-Pelaez M., Crabo B.G., Zaneveld L.J. (1984): Development of an assay to assess the functional integrity of the human sperm membrane and its relationship to other semen characteristics. Journal of Reproduction and Fertility, 70(1): 219-228.

Johnson L.A., Weitze K.F., Fiser P., Maxwell W.M.C. (2000): Storage of boar semen. Animal Reproduction Science, 62(1-3): 143-172.

Jotanović S. \& Savić Đ. (2017): The Boar. 1st ed. Banja Luka, Bosnia and Herzegovina: University of Banja Luka, Faculty of Agriculture.

Knox R.V. (2016): Artificial insemination in pigs today. Theriogenology, 85: 83-93.

Kommisrud E., Paulenz H., Sehested E., Grevle I.S. (2002): Influence of boar and semen parameters on motility and acrosome integrity in liquid boar semen stored for five days. Acta Veterinaria Scandinavica, 43(1): 49-55.

Mapeka M.H., Lehloenya K.C., Nedambale T.L. (2012): Comparison of different extenders and storage temperature on the sperm motility characteristics of Kolbroek pig semen. South African Journal of Animal Science, 42(5): 530-534.

Maroto Martín L.O., Muñoz E.C., De Cupere F., Van Driessche E., Echemendia-Blanco D., Rodríguez J.M., Beeckmans S. (2010): Bacterial contamination of boar semen affects the litter size. Animal Reproduction Science, 120(1-4): 95-104.

Martín L.O.M., Muñoz E.C., Cupere F., Driessche E.V., Echemendia-Blanco D., Rodríguez J.M.M., Beeckmans S., (2010): Bacterial contamination of boar semen affects the litter size. Animal Reproduction Science, 120: 95-104.

Paquignon M., Bussière J., Bariteau F. (1988): Efficacité des techniques de conservation de la semence de verrat. INRA Production Animales, 1(4): 271-280.

Pezo F., Romero F., Zambrano F., Sánchez R. S. (2019): Preservation of boar semen: An update. Reproduction in domestic animals, 54(3): 423-434.

Rath D., Bathgate R., Rodriguez-Martinez H., Roca J., Strzezek J., Waberski D. (2009): Recent advances in boar sperm cryopreservation. Society of Reproduction and Fertility, Supplement, 66: 51-66.

Sancho Badell S. (2002): Efectes del fotoperiode sobre la qualitat espermatica de mascles porcins Sus domesticus. PhD Thesis. Universitat de Girona.

Santos P.M., Bennemann P.E., Rocha J.C., Reis G.M., Calderam K. (2018): Uso do Dicol ${ }^{\circledR}$ como ferramenta de reducao da contaminacao bacteriana do ejaculado suino: efeito sobre a motilidade espermatica de doses inseminates. PORKEXPO 2018 IX Forum Internacional de Suinocultura. Foz do Iguacu/PR, pp. 305-306.

Schulze M., Ammon C., Rüdiger K., Jung M., Grobbel M. (2015): Analysis of hygienic critical control points in boar semen production. Theriogenology, 83: 430-437.

Sone M. (1990): Investigations on the control of bacteria in boar semen. Japan Journal of Animal Reproduction, 36: 23-29.

Suwimonteeraburt J., Thuwanut P., Singlor J., Chatdarong K., Tummaruk P. (2011): Effect of collection extender (Dicol) on cold stored boar sperm viability and bacterial contamination. Thai Journal of Veterinary Medicine, 41: 173-174.

Ubeda J.L., Ausejo R., Dahmani Y., Falceto M.V., Usan A., Malo C, et al. (2013): Adverse effects of members of the Enterobacteriaceae family on boar sperm quality. Theriogenology, 80:565-70.

Vyt P., Maes D., Quinten C., Rijsselaere T., Deley W. Aarts M., de Kruif A., Van Soom A. (2008): Detailed motility evaluation of boar semen and its predictive value for reproductive performance in sows. Vlaams Diergeneeskundig Tijdschrift, 77: 291-298.

Waberski D., Weyand A., Seedorf J., Weitze, K.F. (2010): Hygiene measures in boar semen production. Acta Scientiae Veterinariae, 38 (Suppl. 1): 1-7.

Waberski D., Riesenbeck A., Schulze M., Weitze K. F., Johnson L. (2019): Application of preserved boar semen for artificial insemination: past, present and future challenges. Theriogenology, 137: 2-7.

Yeste M. (2017): State-of-the-art of boar sperm preservation in liquid and frozen state. Animal Reproduction, 14(1): 69-81.

Submitted: 10.7.2019.

Accepted: 25.9.2019. 